\title{
Combining taper and basic wood density equations for estimating stem biomass of the Populus $x$ canadensis $I$ - 488 variety
}

\author{
Combinación de funciones de ahusamiento y densidad básica de la madera para la estimación de la \\ biomasa fustal de Populus x canadensis variedad I - 488
}

\author{
Viviana Flórez $^{\text {a*, }}$, Carlos Valenzuela ${ }^{\text {a }}$ Eduardo Acuña ${ }^{\text {a }}$, Jorge Cancino ${ }^{\text {a }}$ \\ *Autor de correspondencia: ${ }^{a}$ Universidad de Concepción, Facultad de Ciencias Forestales, Departamento de Manejo \\ de Bosque y Medio Ambiente, Casilla 160 - C (F-3), Concepción, Chile, tel.: 56-41-2204979, viviflorez@udec.cl
}

\section{SUMMARY}

Stem biomass estimates are useful for various purposes. For example, the amount of commercially usable timber, carbon stock and energy fuel potential are directly related to biomass quantity. This paper describes the development of a biomass flexible equation for poplar (Populus $x$ canadensis I - 488) combining stem profile and basic wood density models, which were fitted and validated with a sample of 60 trees of this variety of poplar. The biomass equation, which is obtained from the double integral of the product between the basic wood density and cross-sectional stem area, was analyzed in four scenarios given by combining average and individual tree models for both stem profile and basic wood density. The most accurate results in both stem profile and basic wood density modeling, as in the stem biomass estimates, were obtained with individual tree models.

Key words: flexible equation, individual tree equation, stem profile, simultaneous fitting, complementary mass-volume quantification.

\section{RESUMEN}

La cuantificación de la biomasa fustal es útil para variados objetivos. Entre otros, permite estimar la cantidad de madera comercialmente aprovechable, cantidad de carbono almacenado y cantidad potencial de combustible energético que se puede obtener de la biomasa. Este documento describe el desarrollo de una función flexible de biomasa para la variedad de álamo Populus x canadensis, variedad I-488, combinando modelos de perfil fustal y de densidad básica de la madera, los que se ajustaron y validaron con una muestra de 60 árboles. La función flexible de biomasa, que se obtiene de la doble integral del producto entre la densidad básica de la madera y del área de sección transversal del fuste, se evaluó en cuatro escenarios diferentes, resultantes de combinar modelos promedio y de árbol individual tanto de perfil fustal como de densidad de la madera. Los resultados más exactos tanto en las modelizaciones del perfil fustal y de la densidad básica de la madera, como en la estimación de la biomasa, se obtuvieron con los modelos de árbol individual.

Palabras clave: función flexible, función de árbol individual, perfil fustal, ajuste individual simultáneo, cuantificación complementaria másica-volumétrica.

\section{INTRODUCTION}

The stem of trees accumulates the major portion of the above ground lignocellulosic biomass. Thus, determination of stem biomass is of fundamental interest for various purposes. Among others, biomass can be used as an indicator of the amount of timber available for commercial use (e.g. lumber, chips or pulp), the amount of carbon stocks and potential amount of extractable energy fuel wood per unit area (Brown et al. 1989, Navar et al. 2001, Schlegel 2001). It can also be used to compare productivity among individuals, species and sites (Gaillard de Benitez et al. 2000, Segura and Kanninen 2005), in a determined area and time (Brown et al. 1989), allowing the design of suitable management schemes for plantations and natural forests.

The quantification of stem biomass can be performed by direct or indirect methods (Welles and Cohen 1996,
Schlegel 2001, Fonseca et al. 2009). Direct methods entail destructive procedures involving the sectioning of the stem to obtain a sample of stem disks from which the dry mass of the stem is determined. One option is to use the ratio between the dry weight and the fresh weight of the biomass samples; the total dry weight of the stem or a fraction of this is obtained from the product between the weight ratio and the respective fresh weight of each tree. Another more elaborate option, which requires registering the height at which each stem disk was obtained and diameter of each stem disk, is to use the product of the volume and the basic density of the wood; the volume of each stem section, established between each pair of successive stem disks, is obtained from the product between the distance between the stem disks and the average of the respective cross-sectional areas; the basic wood density of the wood is obtained from the ratio of the dry weight of the stem 
disk without bark and its fresh volume. The dry weight of each section is obtained from the product of the respective volume and the average basic density values; the total dry weight of the stem or a fraction thereof, which can be defined in terms of a merchantable top diameter, is obtained from the sum of the dry weights of the respective sections.

Indirect methods are a more practical alternative for estimating stem biomass. In general, they involve the use of allometric models which determine the relationship existing between the stem biomass and easily measurable variables, such as the diameter at breast height (DBH), i.e. the stem diameter measured at $1.30 \mathrm{~m}$ above ground level, and the total tree height (Brown et al. 1989, Myers 1990), or variables derived therefrom such as the square of the diameter and its product with total height (Dieguez et al. 2003). Diameter is one of the most suitable predictors for fitting of this type of models, owing to its high correlation with biomass (Specht and West 2003, Fonseca et al. 2009); in young individuals, it may be more appropriate to use the stump diameter instead (Husch 2001, Pérez and Kanninen 2002). Obviously, the fitting of the models is preceded by a destructive sampling which provides the necessary data (Brown et al. 1989, Diéguez et al. 2003, Muñoz et al. 2005). Although the equations resulting from the fitting permit to estimate the biomass with a high degree of accuracy, its greatest limitation derives from the fact that there are habitually produced equations for fractions of the stem between the stump and the upper part of the stem defined in terms of a fixed merchantable top diameter.

A flexible equation for estimating biomass can be produced from the independent modeling of basic wood density and stem profile. This equation, which allows estimating biomass between any two stem heights, is obtained from the double integral of the product between the stem sectional area, estimated by means of a stem profile model, and basic wood density (Parresol and Thomas 1989); variables modeled depending on the relative height of the stem. The model of Bruce (1968) in its basic form can be used in the modeling of the stem profile, i.e. to obtain an average profile model, and two variants of the same; the first consisting of estimating the exponents of the model from the data available for the poplar variety under study; the second, a single-tree model in which the coefficients of the equation are estimated from the size of the tree. Correspondingly, in the modeling of the basic wood density an average model and an individual tree model can be used. As a result, four scenarios are obtained resulting from combining the stem profile equations obtained from the average and the individual tree fitting with the two equations of basic wood density. We hypothesized that the more precise flexible biomass equation is obtained combining both stem taper and basic wood density equations based on individual-tree effects.

Although the fitting of both models requires the same information as used for fitting traditional biomass models with fixed merchantable top diameter, not only is the equation resulting from the double integral more flexible and useful than those for fixed merchantable top diameter, but also this, in conjunction with the stem profile model, constitutes a simple set of equations that allow the complementary volumetric-mass quantification of the stem. For example, the fraction of stem with dimensions suitable to generate logs destined for sawmills and rotated and laminated veneer may require a volumetric quantification; the remaining stem could be used for bioenergy and require quantification of the mass. Obviously, which fraction of the tree to allocate to what purpose is a matter of supply and demand, in which the price per unit volume or unit biomass plays a determining role. Complementary massvolumetric quantification tools are essential to carry out this analysis.

The objective of this study is to generate a flexible equation for estimating the stem biomass of Populus $x$ canadensis - variety I488 (poplar), which might be very useful for planning the integrated use of the stem, especially in those cases where the stem generates some products that require a volumetric quantification (e.g. logs destined for sawmills, rotated and laminated veneer), while others require a mass quantification (e.g. pulp, bioenergy).

To simplify the double-integral process we used the same explanatory variable for both stem taper and basic wood density equations. This relative stem height explanatory variable is adequate to reduce residual variability and to facilitate the fitting of average stem taper and average basic wood density models. Diameter at breast height (DBH), i.e. the stem diameter measured at $1.30 \mathrm{~m}$ above ground level, and the total tree height were used to evaluate individual-tree effects.

\section{METHODS}

Description of the database. The database used in this study was compiled in 2011 in four stands of the Populus $x$ canadensis I - 488 variety, belonging to Compañía Agrícola y Forestal El Álamo (CAF El Álamo), located in The Retiro city, Maule region, Chile (table 1). They are stands established with ample distances of $6 \mathrm{~m} \times 6 \mathrm{~m}$, i.e. 278 trees per hectare, and maintained with that constant low density until harvest, which is carried out when stands are around 14 years old. In each stand 15 trees were selected, covering the entire diametric range recorded in an inventory conducted in 2010; twelve of these trees were used for the fitting and three, randomly selected, came to constitute the sample for validation of stem profile, basic wood density and stem biomass models.

Measured variables. In each one of the standing trees selected to constitute the sample the diameter at breast height (DBH) was recorded. Once felled, the stump height and total height were recorded. Then sections were cut into $3.3 \mathrm{~m}$ lengths, according to the quality and length of logs predefined by the CAF protocol for finished products, i.e. 
Table 1. Descriptive statistics of the database used in models fitting and validation.

Estadísticos descriptivos de la base de datos usada en el ajuste y validación de los modelos.

\begin{tabular}{|c|c|c|c|c|c|c|c|c|c|c|c|c|c|c|}
\hline \multirow[b]{2}{*}{ Stand } & \multirow{2}{*}{$\begin{array}{l}\text { Age } \\
\text { (year) }\end{array}$} & \multirow{2}{*}{$\begin{array}{l}\text { Site } \\
\text { Index }^{\mathrm{a}} \\
(\mathrm{m})\end{array}$} & \multicolumn{4}{|c|}{$\mathrm{DBH}(\mathrm{cm})$} & \multicolumn{4}{|c|}{ Total height (m) } & \multicolumn{4}{|c|}{$\mathrm{Hc}^{\mathrm{b}}(\mathrm{m})$} \\
\hline & & & Min. & Mean & Max. & $\mathrm{VC} \%{ }^{\mathrm{c}}$ & Min. & Mean & Max. & VC\% & Min. & Mean & Max. & VC\% \\
\hline \multicolumn{15}{|c|}{ Sample used in models fitting } \\
\hline 1 & 16 & 24.73 & 23.5 & 32.7 & 38.0 & 12.8 & 29.3 & 33.2 & 36.2 & 7.0 & 12.6 & 17.2 & 22.7 & 15.2 \\
\hline 2 & 15 & 24.28 & 23.1 & 29.5 & 34.1 & 8.8 & 28.6 & 30.5 & 32.1 & 3.0 & 14.2 & 16.5 & 18.0 & 7.7 \\
\hline 3 & 14 & 34.35 & 30.9 & 34.8 & 40.0 & 6.9 & 33.8 & 35.3 & 36.6 & 2.3 & 15.3 & 18.9 & 20.8 & 8.5 \\
\hline 4 & 14 & 29.70 & 28.0 & 32.6 & 36.0 & 9.0 & 33.4 & 34.9 & 36.1 & 2.3 & 12.1 & 16.7 & 20.9 & 15.0 \\
\hline \multicolumn{15}{|c|}{ Sample used in models validation } \\
\hline 1 & 16 & 24.73 & 26.8 & 29.6 & 31.7 & 7.1 & 30.4 & 31.6 & 33.2 & 3.8 & 15.9 & 16.7 & 17.5 & 4.0 \\
\hline 2 & 15 & 24.28 & 21.6 & 26.6 & 30.6 & 13.8 & 29.0 & 29.6 & 30.2 & 1.7 & 13.4 & 15.7 & 17.1 & 11.1 \\
\hline 3 & 14 & 34.35 & 34.6 & 36.8 & 40.8 & 7.7 & 35.0 & 35.2 & 35.5 & 0.7 & 15.9 & 18.5 & 20.1 & 10.3 \\
\hline 4 & 14 & 29.70 & 30.2 & 32.4 & 34.7 & 5.8 & 33.8 & 35.0 & 35.7 & 2.4 & 17.6 & 19.4 & 20.3 & 6.4 \\
\hline
\end{tabular}

${ }^{\text {a }}$ Mean height at base age 10 yrs.; ${ }^{\mathrm{b}}$ Height to living crown; ${ }^{\mathrm{c}}$ variation coefficient.

from the stump height and up to a top merchantable diameter not inferior to $15.2 \mathrm{~cm}$; thence and up to a top merchantable diameter not less than $10.2 \mathrm{~cm}, 2.5 \mathrm{~m}$ logs were obtained. At the ends of each log, stem disks were obtained which were marked, labeled and stored for later processing in order to obtain their bark thickness, the basic density of the wood and the normal diameter over-bark, i.e. the diameter perpendicular to the ground in the position in which the stem of felled trees remained. In the middle of the length of each one of the logs, and at the heights of $80,130,180,280 \mathrm{~cm}$ of the base log of each tree, the normal diameter over-bark was recorded. The bark thickness corresponding to the diameters measured in the logs was estimated by linear interpolation, using the measuring height and bark thickness from the stem disks obtained at the end of each log.

Basic wood density was determined from the ratio of the dry weight and the green volume of an angular sample in each one of the stem disks. Dry weight without bark was obtained with an electronic balance with a precision of $0.01 \mathrm{~g}$, after dried in an oven at $105{ }^{\circ} \mathrm{C}$, until reaching a constant weight. The green volume was determined by the liquid displacement method, with electronic balance with accuracy of $0.1 \mathrm{~g}$, assuming water density of $1 \mathrm{~g} \mathrm{~cm}^{-3}$. The angular sample comprised a sector angle of $30^{\circ}$ with the center in the pith and comprising up to the outermost part of each stem disk and located on the average radius of the stem disk, which was obtained from a series of radial measurements.

Stem profile modeling. In the modeling of the stem profile three alternatives were considered. The first consisted of the average model fitting (model 1), which corresponds to a basic model proposed by Bruce et al. (1968), in which fixed values were assigned to the exponents. The second consisted of fitting an average model, but estimating the exponents $e_{i}$ of the model from the stem taper data available for this study. The third consisted of fitting an individual tree stem profile model, in which the coefficients $b_{i}$ of the basic model were estimated based on the diameter at breast height (D), total height $(\mathrm{H})$, height of live tree crown $\left(H_{c}\right)$ and combinations thereof, i.e. $b_{i}=\mathrm{f}\left(1 \mathrm{DH} \mathrm{D}^{2} \mathrm{H}^{2} D H\right.$ $D^{2} H H C D^{2} H_{c}$ ). This individual model took the best set of exponents as a base, from between the first two options.

Relative values were used to adjust the taper model into the model to express the incorporated variables. These variables can also be directly incorporated. However, it is more useful to define them as relative values, because the variability of the dependent variable decreases; a basic requirement of the traditional regression technique (Raymond et al. 1989), and it is easier to visualize the relationship among variables. In this way, the definition of the dependent variable was guided by the ultimate use of the taper function. This is because when transforming the dependent variable of the function set and the value of a specific variable needs to be estimated, bias can be introduced between any two points of the stem in the estimates.

$\mathrm{y}_{\mathrm{i}}^{2}=\mathrm{b}_{1} \mathrm{x}_{\mathrm{i}}^{\mathrm{e}}+\mathrm{b}_{2} \mathrm{x}_{\mathrm{i}}^{\mathrm{e}_{2}}+\mathrm{b}_{3} \mathrm{x}_{\mathrm{\beta}}^{\mathrm{e}^{3}}+\varepsilon_{\mathrm{i}}$

with $y_{i}=\frac{d_{i}}{D}$ and $x=\left(\frac{H-h}{H-1,3}\right)$

Where,

$d_{i}=$ is the diameter under-bark (cm).

$h_{i}(\mathrm{~m})=$ height in the stem. 
$D=$ is the diameter over-bark at breast height $(\mathrm{cm})$.

$H=$ is the total height of the tree $(\mathrm{m}), b_{i}$ and $e_{i}$ are the parameters of the model, and $\varepsilon_{\mathrm{i}}$ is the residual.

Basic wood density modeling. In the modeling of basic wood density two alternatives were considered, taking a three parameters polynomial model as a base, which best describes the relationship between the wood basic density and tree heights (Fang and Yang, 2003) (model 2). The first consisted of the average model fitting; the second consisted of a single tree model fitting, in which the coefficients $a_{i}$ were estimated based on tree state variables, i.e. $\mathrm{a}_{\mathrm{i}}=\mathbf{f}$ (1 $D H D^{2} H^{2} D H D^{2} H H C D^{2} H_{C}$ ).

$\rho_{\mathrm{i}}=\mathrm{a}_{0}+\mathrm{a}_{1} \mathrm{x}_{\mathrm{i}}^{0,5}+\mathrm{a}_{2} \mathrm{x}_{\mathrm{i}}^{3}+\varepsilon_{\mathrm{i}}$

Where,

$\rho_{\mathrm{i}}$ is the basic density of the wood $\left(\mathrm{kg} \mathrm{m}^{-3}\right)$ at the relative height $x_{i}$ in the stem, $a_{i}$ are the model parameters and $\varepsilon_{\mathrm{i}}$ is the residual.

Models fitting and comparison. In the fitting of the models the SAS statistical software (SAS 2009) was used. In the linear model fitting the PROC REG was used, while the fitting of the second alternative stem profile model was performed using PROC NLIN in SAS. This procedure fits nonlinear regression models, segmented models or robust regression, and estimates the parameters by nonlinear least squares or weighted nonlinear least squares. Furthermore, it gives reasonable starting values for successful convergence. The selection of predictor variables, in the fitting of individual tree stem profile and basic wood density models, was performed with the PROC REG and SELECTION = STEPWISE, a conditioning with the intention that each final model might include the predictor variables typical of the best average stem profile model, i.e. $\mathbf{X}_{i}^{\mathrm{e}}$, $x_{i}^{e_{2}}$ and $x_{i}^{e_{3}}$, and, respectively, the average basic wood density model, i.e. $\mathbf{X}_{i}^{0,5}$ and $\mathbf{X}_{i}^{3}$. Model comparison was made using the root mean square residual (3) and Akaike's index (4) (AIC; Akaike 1974, Wagenmakers and Farrell 2004). The model validation was performed based on the accuracy (5) (Bruce 1975).

$$
\begin{aligned}
& \mathrm{RMSE}=\sqrt{\mathrm{SSE} /(\mathrm{n}-\mathrm{p})} \\
& \mathrm{AIC}=\mathrm{n} \ln (\mathrm{SSE} / \mathrm{n})+2 \mathrm{p} \\
& \mathrm{E}=\sqrt{\bar{\varepsilon}^{2}+\mathrm{s}^{2}}
\end{aligned}
$$

Where,
$S S E=$ is the sum of squared residuals (i.e. $\sum_{\mathrm{i}=1}^{\mathrm{n}}\left(\mathrm{y}_{\mathrm{i}}-\hat{y}_{\mathrm{i}}\right)^{2}$ ).

$p=$ is the number of model parameters.

$n=$ is the total number of observations.

$\bar{\varepsilon}_{2}=$ is the average deviation (i.e. $\sum_{\mathrm{i}=1}^{\mathrm{n}} \varepsilon_{\mathrm{i}} / \mathrm{n}$ ).

$\mathrm{S}^{2}=$ is the variance of residuals (i.e. $\sum_{i=1}^{n}\left(\varepsilon_{i}-\bar{\varepsilon}\right)^{2} /(\mathrm{n}-1)$ ).
Stem biomass estimation. Stem biomass was determined from the double integral of the product between the stem cross-sectional area, obtained from a taper model, and the basic density of the wood (Parresol and Thomas 1989) (model 6).

$\hat{w}_{i}=(1,3-H) \int_{x_{i}}^{x_{u}} \int_{0}^{f\left(x_{i}\right)} \hat{\rho}_{i}\left(x_{i}, y_{i}\right) \partial y \partial x$

Where,

$\hat{W}_{i}=$ is the dry weight $(\mathrm{kg})$ of the stem section between the relative heights $X_{1}$ and $X_{u}$.

$f\left(x_{i}\right)=$ is the equation of the transversal area of the stem, obtained from the stem profile model, i.e.

$\mathrm{f}_{n}\left(\mathrm{x}_{\mathrm{i}}\right)=\mathrm{kD}^{2}\left[\mathrm{~b}_{1} \mathrm{x}_{\mathrm{i}}^{\mathrm{e}}+\mathrm{b}_{2} \mathrm{x}_{\mathrm{i}}^{\mathrm{e}_{2}}+\mathrm{b}_{3} \mathrm{x}_{\mathrm{i}}^{\mathrm{e}_{3}}\right]$ and $\mathrm{k}=\pi / 40000$ $\hat{\rho}_{\mathrm{i}}=$ is the basic wood density equation (i.e. $\hat{\rho}_{\mathrm{i}}=\mathrm{a}_{0}+\mathrm{a}_{1} \mathrm{x}_{\mathrm{i}}^{\mathrm{e}}+\mathrm{a}_{2} \mathrm{x}_{\mathrm{i}}^{\mathrm{e}_{2}}$ ). Thus, the general solution of the double integral was defined as follows (model 7):

$$
\hat{W}_{i}=\left.(1,3-H) k D^{2}\left\{\begin{array}{l}
b_{1} x_{i}{ }^{e}\left(\frac{\left(a_{0} x_{i}\right.}{e_{1}+1}+\frac{a_{1} x_{i}^{1,5}}{e_{1}+1,5}+\frac{a_{2} x_{i}^{4}}{e_{1}+4}\right) \\
+b_{2} x_{i}^{e_{2}}\left(\frac{a_{0} x_{i}}{e_{2}+1}+\frac{a_{1} x_{i}^{1,5}}{e_{2}+1,5}+\frac{a_{2} x_{i}^{4}}{e_{2}+4}\right) \\
+b_{3} x_{i}^{e_{3}}\left(\frac{a_{0} x_{i}}{e_{3}+1}+\frac{a_{1} x_{i}^{1,5}}{e_{3}+1,5}+\frac{a_{2} x_{i}^{4}}{e_{3}+4}\right)
\end{array}\right)\right|_{x_{u}} ^{x_{1}}
$$

The analysis of the biomass predictive model (model 7) was performed contrasting the real biomass estimates, which were obtained from the data of size and spacing between stem disks and basic wood density (8). Model 8 is the product of the solid volume of stem section, estimated by means of the formula of Smalian, i.e. $V=\left(A_{b}+A_{5}\right) \cdot L / 2$, and the average basic wood density of the section, a value corresponding to the average of the densities of the stem disks at the ends of each section weighted by the corresponding sectional areas, i.e. $\bar{\rho}=\left(\rho_{\mathrm{b}} \mathrm{A}_{\mathrm{b}}+\rho_{\mathrm{s}} \mathrm{A}_{\mathrm{s}}\right)\left(\mathrm{A}_{\mathrm{b}}+\mathrm{A}_{\mathrm{s}}\right)$.

$\hat{\mathrm{W}}_{\mathrm{r}}=\left[\frac{\mathrm{A}_{\mathrm{b}} \rho_{\mathrm{b}}+\mathrm{A}_{\mathrm{s}} \rho_{\mathrm{s}}}{2}\right] \cdot \mathrm{L}$

Where,

$\mathbf{W}_{r}=$ is the dry weight $(\mathrm{kg})$ of the stem section between two successive stem disks in the trunk of a tree, which was assumed as the actual value for the purposes of this study. $\mathrm{A}_{\mathrm{b}}, \mathrm{A}_{\mathrm{s}}$ and $\rho_{\mathrm{b}}, \rho_{\mathrm{s}},=$ respectively, are the section areas $\left(\mathrm{m}^{2}\right)$ and the basic densities of the wood $\left(\mathrm{kg} \mathrm{m}^{-3}\right)$ of the basal and upper stem disks of each stem section.

$L=$ is the length of the section (m).

The analyses of the predictive quality of the biomass model were made at tree level and log level. The biomass of each tree was obtained from the summation of the biomass of the sections along the stem. In both cases, the analyses included the separation according to size classes, i.e. small-end diameter classes for logs and DBH classes 
for trees. Analyses were carried out in four different scenarios, resulting from combining two stem profile models, i.e. the best average stem profile model and the individual tree profile model, with the two basic wood density models, i.e. the average and the individual tree models. Thus, the first scenario resulted from the combination between the best average stem profile model and the average basic wood density model; the second scenario combined the best average stem profile model and the individual tree basic density wood model; the third scenario combined the individual tree stem model profile and the average basic wood density model; the fourth scenario resulted from combining the individual tree models for both stem profile and basic wood density. Analyses were made based on accuracy $(E)$.

\section{RESULTS}

Stem profile modeling. The average fitting of the basic model of Bruce et al. (1968) was unsatisfactory. Although the estimators of the regression coefficients were significant (table 2), graphical analyses show that the model is not flexible enough to properly emulate the trend observed from the stem profile in this variety of poplar; the model tends to overestimate in the middle-upper portions of the stem and in that close to the base of the trees, and tends to underestimate the middle-lower part (figure 1). That deficiency, which is evident in the sample used for the fitting (figure 1, left), is also evident when using the model in each sampled stand (figure 1, right).

The average stem profile modeling significantly improved when estimating the exponents of the model from the available information. This result was achieved with a slight increase in the exponent $e_{1}$, i.e. from 1.5 to 1.6628 , and significant increases in $e_{2}$ and $e_{3}$, i.e. from 3 to 5.3280 and, respectively, from 32 to 45.8188 (table 2). With these new exponent values, the model acquires sufficient flexibility to properly emulate the trend observed in the stem profile of this variety of poplar (figure 2; compared with figure 1), eliminating the shortcomings shown in the basic model of Bruce et al. (1968). Although this variant of the basic model of Bruce et al. (1968), as in the remainder of this document will be named "modified Bruce ", requires the estimation of six parameters, i.e. three coefficients and three exponents, it presented an index of Akaike $3.26 \%$ smaller, the root mean square residual error was reduced by $9.45 \%$, whereas the accuracy increased by $9.44 \%$. The best fitting of the model, which is evident in the sample used for the fitting (figure 2, left), is also evident on using the model in each particular stand (figure 2, right).

Incorporating tree state variables significantly improved stem profile modeling. The fitting at individual tree level, using the set of exponents determined as suitable for the average stem profile model for this variety of poplar, reduced in $5.74 \%$ the mean square root residual error compared to the average model and exponents estimated from the available data, and in $14.66 \%$ in comparison with the average model of Bruce et al. (1968). The reduction in the Akaike's index reached, respectively, $1.82 \%$ and 5.14 $\%$, and the accuracy increased $96.56 \%$ and $96.20 \%$. In all models, the larger residuals are observed at the base of the stems due to the deformations that they present in that area (figure 3). The variables of the state of the tree with significant effect on coefficients $b_{1}$ and $b_{3}$ of the stem profile model were $H, D H, D^{2} H$, y $H^{2}$; no effect was detected on tree size upon the coefficient $b_{2}$ (table 2).

Basic wood density modeling. Although average model fitting generated significant parameters (table 3), seeming to

Table 2. Estimators and statistics from the fitting of the stem profile models. Estimadores y estadísticos del ajuste de los modelos de perfil fustal.

\begin{tabular}{cccc}
\hline \multirow{2}{*}{ Parameters } & \multicolumn{2}{c}{ Average model } & Individual tree model \\
\cline { 2 - 3 } & Bruce et al. $(1968)$ & Modified Bruce & 1.6628 \\
$\mathrm{e}_{1}$ & 1.5 & 1.6628 & 5.3280 \\
$\mathrm{e}_{2}$ & 3 & 5.3280 & 45.819 \\
$\mathrm{e}_{3}$ & 32 & 45.819 & $0,82535^{(* *)}+0,000655022 \mathrm{DH}^{(* *)}-0,00001245 \mathrm{D}^{2} \mathrm{H}^{(* *)}$ \\
$\mathrm{b}_{1}$ & $1.0571^{(*)}$ & $1.0890^{(*)}$ & $-0.26359^{(* *)}$ \\
$\mathrm{b}_{2}$ & $-0.2120^{(*)}$ & $-0.2554^{(*)}$ & \\
$\mathrm{b}_{3}$ & $0.08354^{(*)}$ & $0.0645^{(*)}$ & $0,083253^{(* *)}-0,00329291 \mathrm{H}^{(* *)}+0,000087504 \mathrm{DH}^{(* *)}$ \\
\hline Statistics of fitting & & & 0.04052 \\
\hline$R M S E$ & 0.0475 & 0.0429 & -6552.47 \\
AIC & -6232.2 & -6435.41 & 0.001632 \\
$E$ (Fitting) & 0.04743 & 0.04295 & 0.02764 \\
$E$ (Validation) & 0.03171 & 0.02678 & \\
\hline
\end{tabular}

*: $P<0.05$; **: $P<0.001 ;$ RMSE: root of the mean square residual; AIC: Akaike index; E: accuracy. 

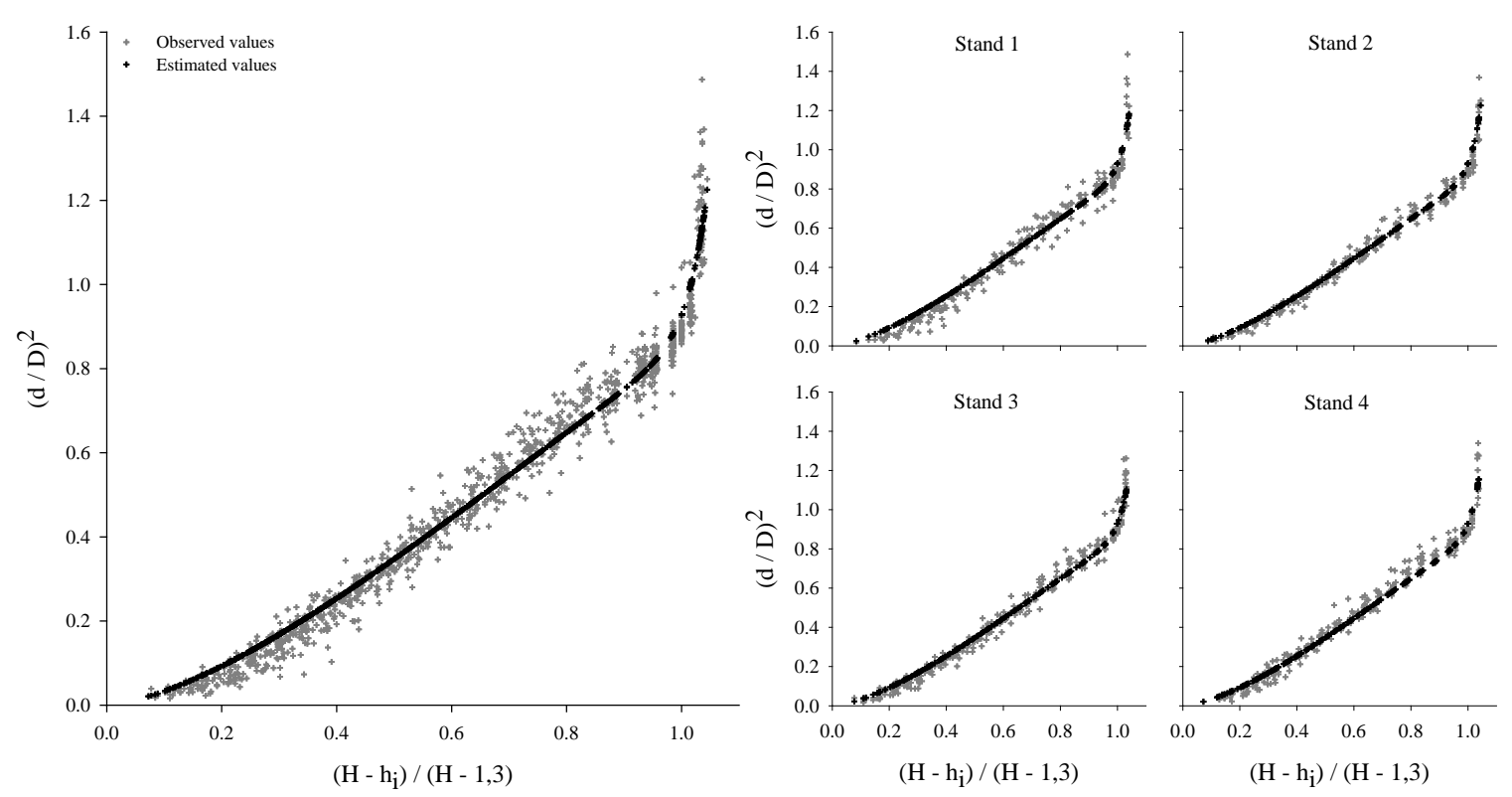

Figure 1. Graph of the basic stem profile model of Bruce et al. (1968) resulting from the average fitting, showing in gray the observation and in black the estimation curve. Left: the estimation curve and the observations of the four stands used in the model fitting; right: the estimation curve and the observations of each stand in the sample.

Gráfica del modelo de perfil fustal básico de Bruce et al. (1968) resultante del ajuste promedio, mostrando en gris las observaciones y en negro la curva de estimación. Izquierda: la curva de estimación y las observaciones de los cuatro rodales utilizadas en el ajuste del modelo; derecha: la curva de estimación y las observaciones de cada rodal en la muestra.
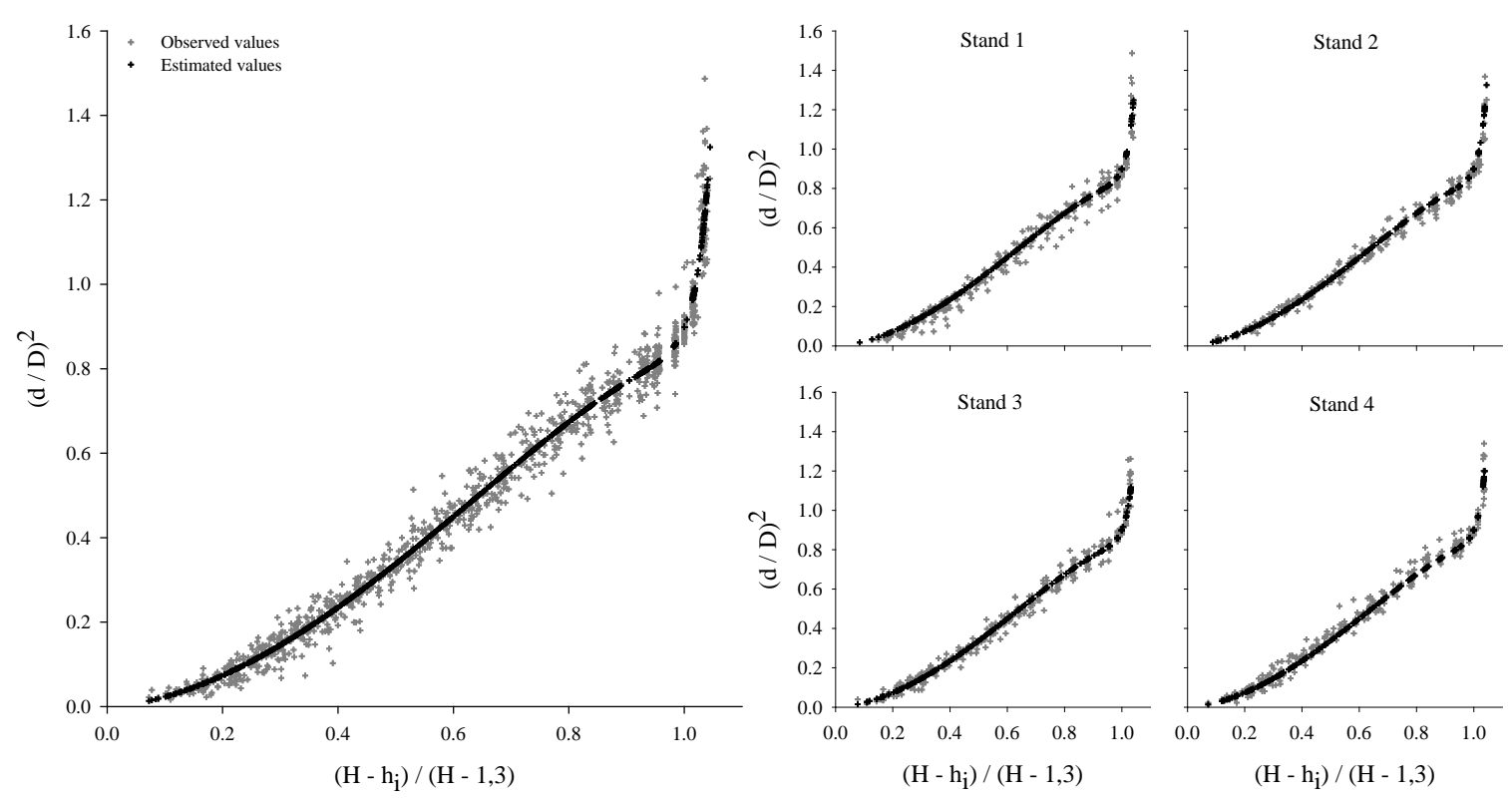

Figure 2. Graph of basic stem profile model Bruce et al. (1968) resulting from the fitting average, but estimating the model exponents $e_{i}$ of the model from the stem taper data available for this study, i.e. "Bruce modified" model. The observations are shown in gray; in black, the estimation curve. Left: the estimation curve and the observations from the four stands used in the model fitting; right: the estimation curve and the observations from each stand in the sample.

Gráfica del modelo de perfil fustal básico de Bruce et al. (1968) resultante del ajuste promedio, pero estimando los exponentes $e_{i}$ del modelo a partir de la información de ahusamiento fustal disponible para este estudio, i.e. modelo "Bruce modificado". Las observaciones se muestran en gris; en negro, la curva de estimación. Izquierda: la curva de estimación y las observaciones de los cuatro rodales utilizadas en el ajuste del modelo; derecha: la curva de estimación y las observaciones de cada rodal en la muestra. 

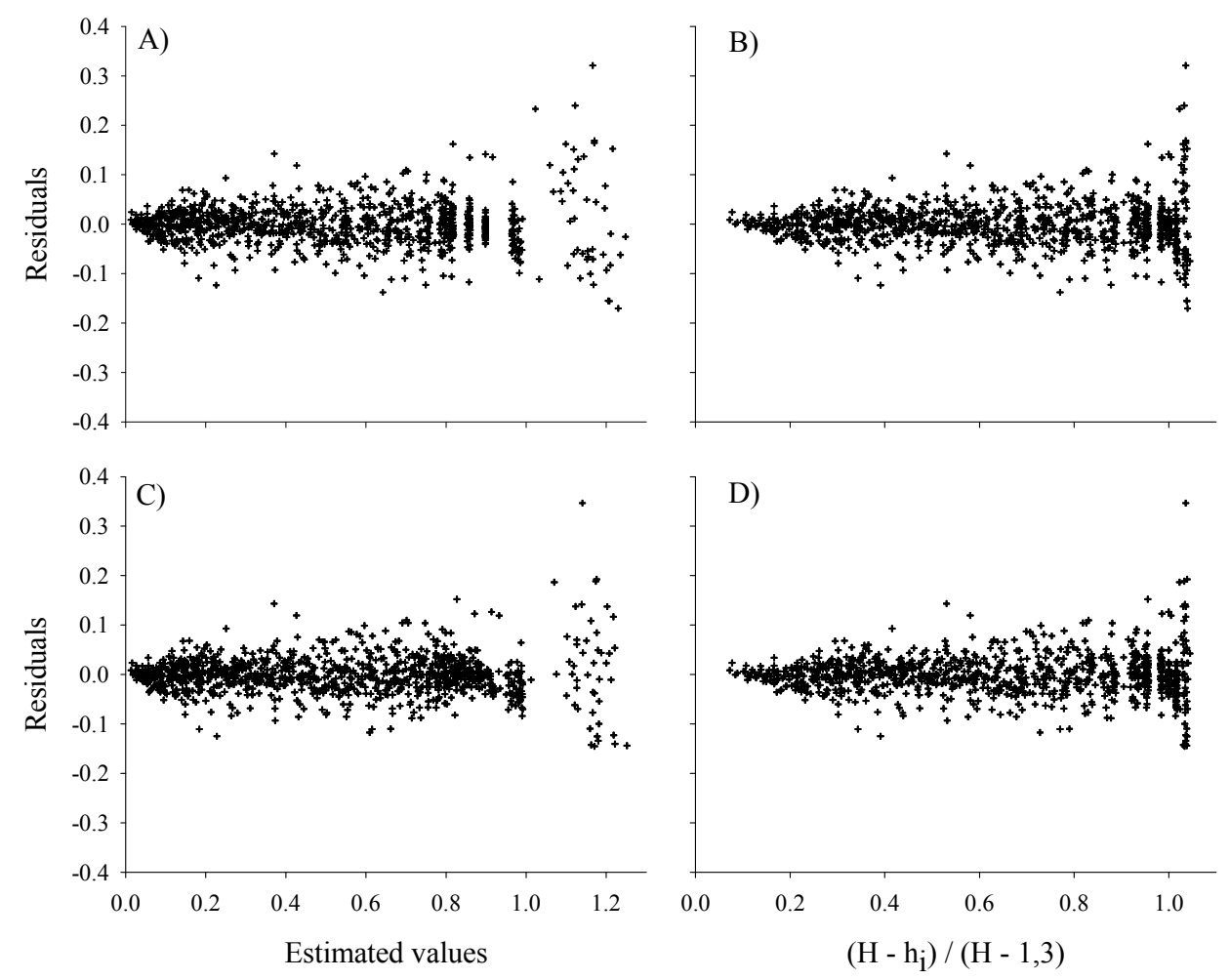

Figure 3. Graphic of stem profile residuals. Left: residuals against estimated values; right: residuals against stem relative height. A) and B) fitting of modified Bruce model; C) and D) fitting of the individual tree model.

Gráfica de residuos. Izquierda: residuos contra valores estimados; derecha: residuos contra altura fustal relativa. A) y B): ajuste del modelo de Bruce modificado; C) y D) ajuste del modelo de árbol individual.

Table 3. Estimators and statistics of basic wood density models.

Estimadores y estadísticos del ajuste de los modelos de densidad básica de la madera.

\begin{tabular}{ccc}
\hline Parameters & Average model & Individual tree model \\
\hline $\mathrm{a}_{0}$ & $453.7000^{(*)}$ & $454.3532^{(* *)}$ \\
$\mathrm{a}_{1}$ & $-89.06250^{(*)}$ & $-143,372^{(* *)}+9,21683 \mathrm{D}^{(* *)}-0,22431 \mathrm{DH}^{(* *)}$ \\
$\mathrm{a}_{2}$ & $-18.65460^{(*)}$ & $-18.72341^{(* *)}$ \\
\hline Fitting statistics & & 12.25616 \\
\hline RMSE & 15.65760 & 2324.565 \\
AIC & 2549.382 & 12.20312 \\
$E$ (Vitting) & 15.62377 & 12.31957 \\
\hline
\end{tabular}

*: $P<0.05$; **: $P<0.001 ;$ RMSE: root of mean square error; AIC: Akaike index; $E$ : accuracy.

adequately represent the sinusoidal trend of increasing basic density of wood from the base to the apex of the variety of poplar studied (figure 4, left), the model is not satisfactory to be used at stand level (figure 4, right). Thus, the presence of a local effect important in the determination of the basic density of the wood is evident, which can be explained, at least partially, incorporating variables of the state of the tree.
The incorporation of tree state variables significantly improves the modeling of the basic wood density. The fitting at individual tree level reduced by $21.72 \%$ the average squared residual root in comparison with the average model. The reduction in the Akaike's index reached $8.82 \%$; the accuracy increased $21.89 \%$. In both models, the greater residues are observed at the base of the stems (figure 5). The state 

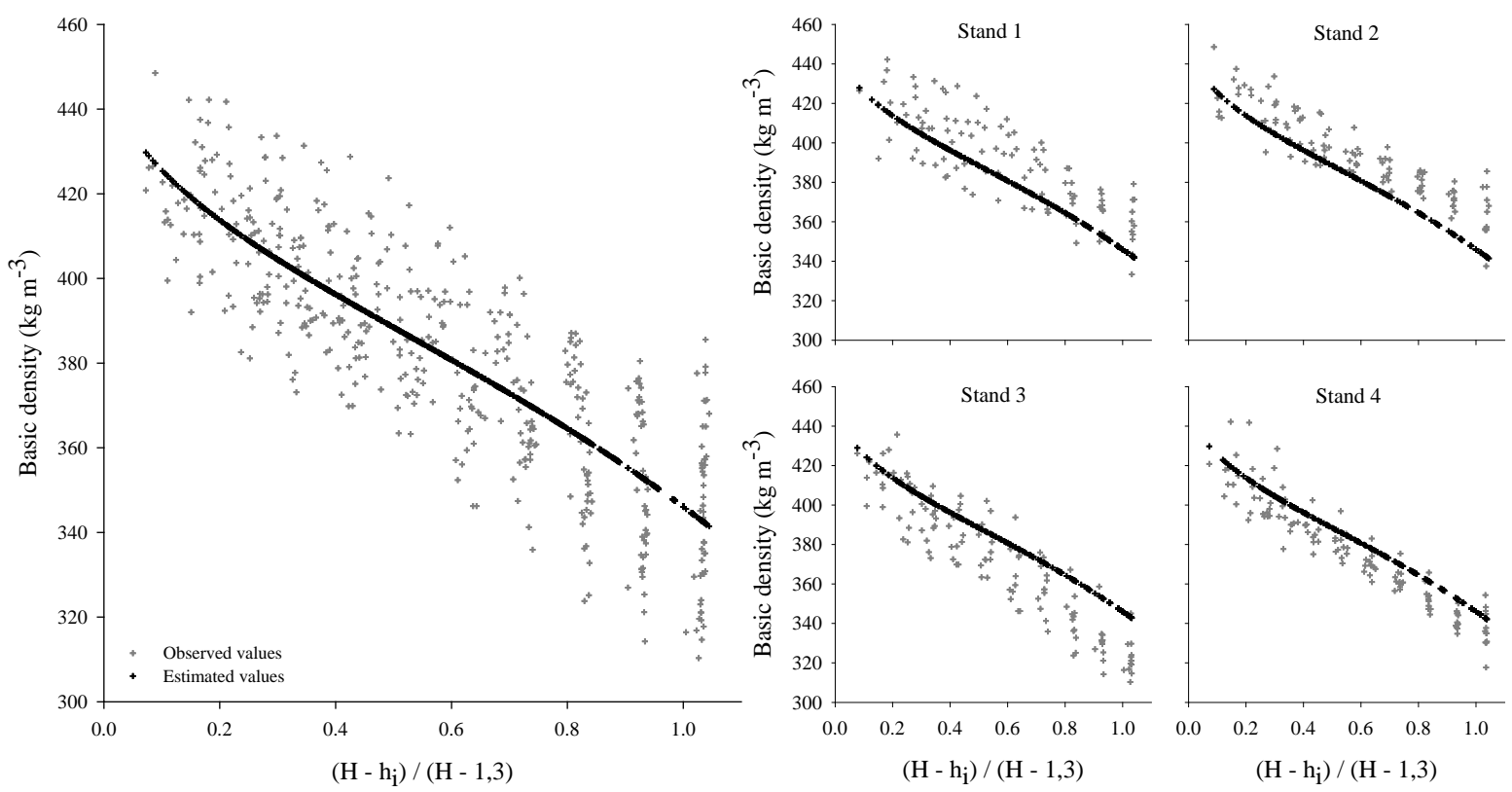

Figure 4. Graph of the basic wood density model resulting from average fitting. Observations are shown in gray; in black, the estimation curve. Left: the estimation curve and observations from the four stands used in model fitting; right: the estimation curve and observations from each stand in the sample.

Gráfica del modelo de densidad básica de la madera resultante del ajuste promedio. Las observaciones se muestran en gris; en negro, la curva de estimación. Izquierda: la curva de estimación y las observaciones de los cuatro rodales utilizadas en el ajuste del modelo; derecha: la curva de estimación y las observaciones de cada rodal en la muestra.
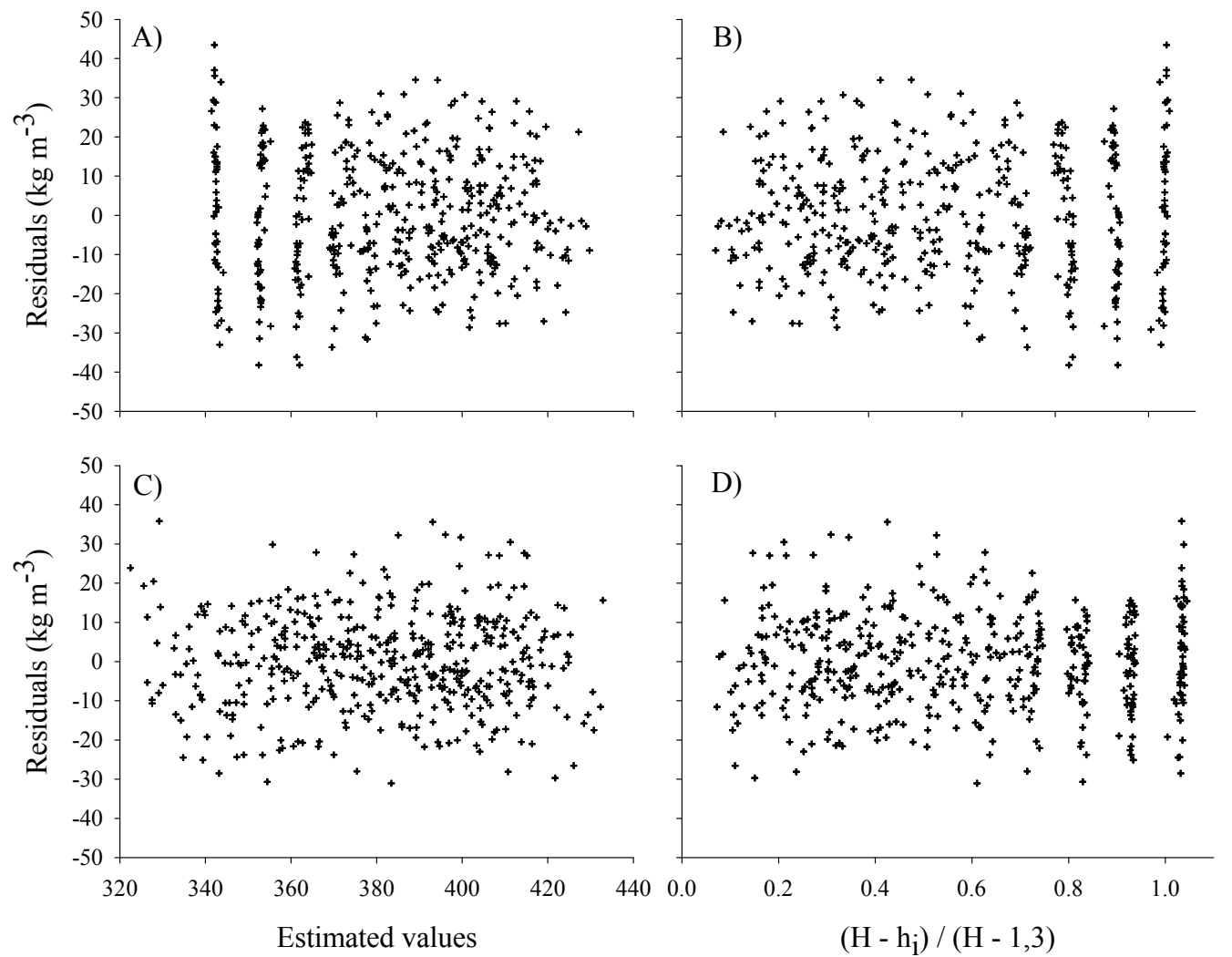

Figure 5. Graphic of basic wood density residuals. Left: residuals against estimated values; right: residuals against relative stem height. A) and B) fitting of the average basic wood density model; C) and D) fitting of the individual tree model.

Gráfica de residuos. Izquierda: residuos contra los valores estimados; derecha: residuos contra altura fustal relativa. A) y B): ajuste del modelo promedio de densidad básica de la madera; C) y D) ajuste del modelo del árbol individual. 
variables of the tree with significant effect on the coefficient $a_{1}$ of basic wood density were $D$ and $D H$; no tree size effect was detected on the coefficients $a_{0}$ and $a_{2}$ (table 3 ).

Stem biomass estimation. The predictive quality of the biomass equation varied depending on the scenario of analysis, i.e. on which stem profile (model 1) and basic wood density (model 2) equations are combined in the double integral (model 7). Both at log level and at tree level the superior accuracy was achieved with the combination of individual tree equations (scenario 4). In the analyses at log level (table 5), carried out on the sample used in the fitting of stem profile and basic wood density, the combination of individual tree models achieved an average accuracy of 3.5985 $\mathrm{kg} \log ^{-1}$, i.e. $4.2 \%$ more accurate than scenario 2; even less accurate, and in descending order, were the combinations of scenarios one and three. No evidence of significant effect of the size of logs on the accuracy was detected. These results agree with those obtained in the validation sample, except for the slight advantage of scenario 3 over 2 and a slight tendency to decrease the accuracy in large diameter logs. It is likely that the slight advantage of scenario three over two is due to the unrestricted random choice of the validation sample, which included individuals of smaller $\mathrm{DBH}$ and greater variability than those present in the fitting sample (compare both samples from stand 2, table 1).

In the analyses at tree level (table 4), carried out on the sample used in the fitting of stem profile and basic wood density equations, the combination of individual tree models (scenario 4), achieved an average accuracy of $23.6 \mathrm{~kg}$ tree $^{-1}$, i.e. $6.50 \%, 8.03 \%$ and $8.83 \%$ more accurate than the combinations of models considered in scenarios two, one and three respectively. There was no evidence of significant effect of tree size on the accuracy of the estimation of stem biomass. These results coincide with those obtained in the validation sample, except the slight advantage of scenario three over two, which would be explained by the smaller DBH size of a stand in the validation sample, as mentioned in preceding paragraphs.

\section{DISCUSSION}

Stem diameter varies not only along the stem but also among species and among individuals of the same species. Thus, a major problem in estimating stem diameter at specific stem points is to fit a taper model that is applicable to trees of different sizes (Earikäinen 2001). The results of this study allow the assertion that, in the variety of poplar analyzed, the bigger difficulty in modeling stem taper is located in the lower part of the stem, by the larger irregularities which it presents in this area. The exponents of the average basic model of Bruce et al. (1968) do not give enough flexibility to follow the trend observed for the stem profile and, as a result, the average resulting equation considering these exponents generates overestimations and underestimations in extensive areas of the stem; results that agree with those observed by Barrio et al. (2007), who found the same pattern of deficiency in diameter along the stem when they used an average stem profile model to calculate the diameter and volume of Populus x euramericana trees. A significant increase in accuracy is achieved by estimating the value of exponents of the stem profile model from the data available; the average equation fitted considering these new exponents properly emulates the taper trend data. The incorporation of state variables of the tree also produces accuracy increase of the fitted equation. Thus, the most precise profile model results from simultaneous individual fitting, with exponents estimated from specific taper data from the species in question.

Basic wood density, defined as the dry wood mass per unit volume of green wood, is a characteristic of high variability. Among others, it varies with age, environmental conditions, availability of water and nutrients in the soil, silvicultural management and among species (Prado and Barros 1989, Kohyama and Hotta 1990, Harris and Cown 1991, Downes et al. 1997, Zobel and Sprague 1998, Peredo et al. 2007, Moya et al. 2009). In turn, it can vary widely within the same tree, longitudinally from the pith to the bark (at different ages) and axially from the base to the apex (Zobel and Talbert 1988). According to the results of this study, the basic wood density of the Populus I - 488 variety increases from the base to the apex of the trees; results that agree with those reported by several authors in different types of hardwoods, including species such as Populus deltoides CV, Acacia melanoxylon R.Br., Eucalyptus grandis Hill ex Maiden, Eucalyptus regnans F. Muell., Eucalyptus globulus Labill and Eucalyptus nitens (Deane et Maiden) (Igartúa et al. 2002, McKinley et al. 2002, Fang and Yang 2003, Díaz et al. 2010, Igartúa and Monteoliva 2010). Other studies have reported for the genus Eucalyptus an initial reduction in basic density between the base and DBH height, and then an increase toward the apex (Bhat et al. 1990, Clark 2001, Raymond and Muneri 2001, Monteoliva et al. 2002). This trend was also observed in clones of the genus Populus (Beaudoin et al. 1992, Gutiérrez and Baonza 2001). The poplar variety considered in the present study did not present such behavior in the basal zone, but the pattern of variation for heights above DBH coincides with that reported in the cited studies. As a consequence, the modeling of the basic wood density of this variety of poplar could be carried out with models more parsimonious than in other varieties. In the modeling of the basic wood density along the stem, the individual tree model achieves higher accuracy than that achieved in the average model.

The estimation of the stem biomass combining stem profile models with basic wood density models is an attractive option not only for the high level of accuracy achieved but also for the flexibility of the resulting equation of the double integral. Although in the fitting of both models the same data as that required for fitting biomass models with fixed top merchantable diameter is used, the resulting equation is more flexible and useful than those 


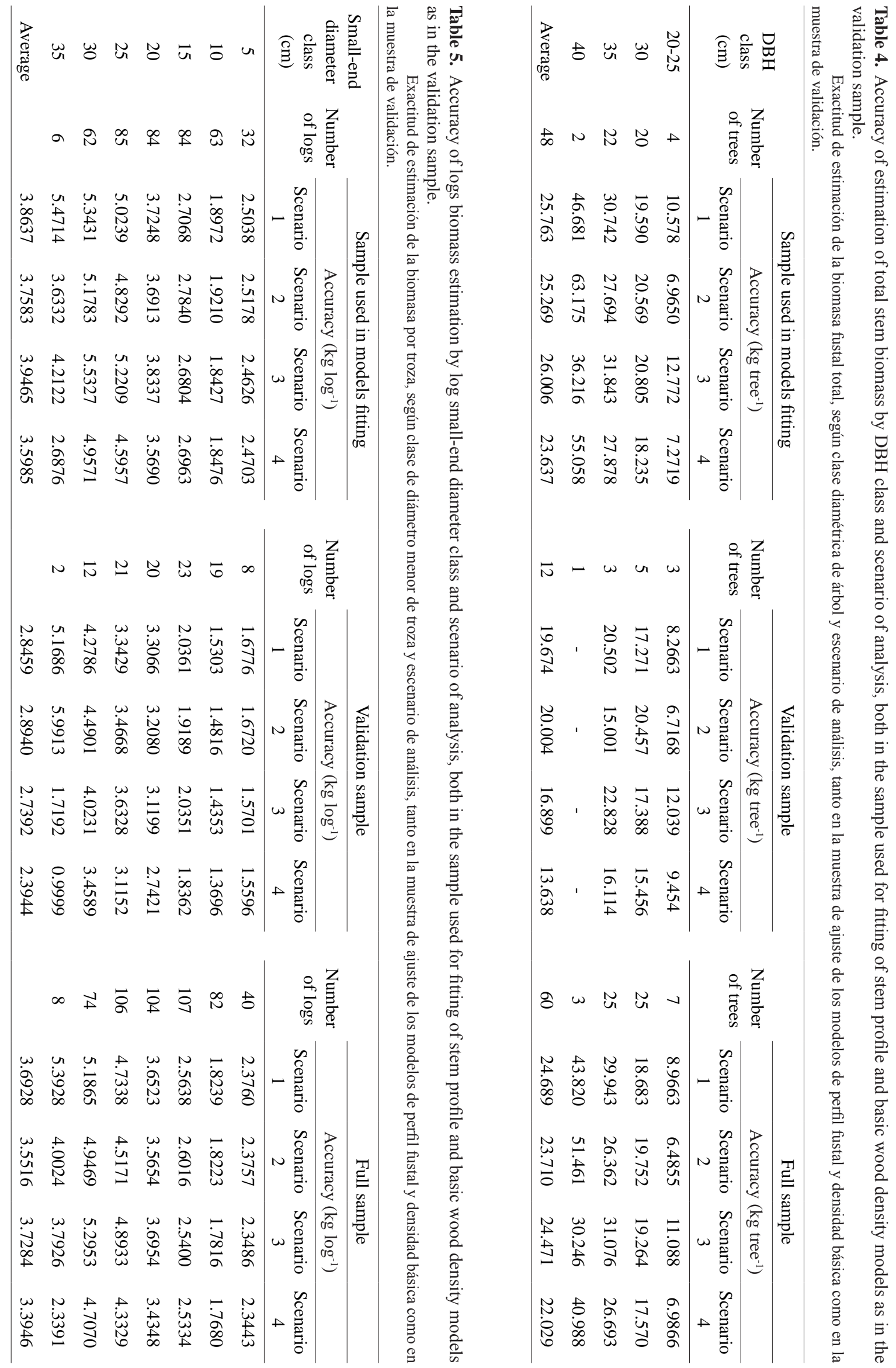


of fixed top merchantable diameter and this, together with the stem profile model, constitutes a simple set of equations that allows complementary volumetric-mass quantification of the stem. For example, the taper equation can be used for the volumetric quantification of the fraction of stem with suitable dimensions to generate logs destined for sawmilling and laminated and rotated veneer; the biomass equation can be used for the mass quantification of the remaining stem that could be used for bioenergy. Obviously, the accuracy of the biomass estimates depends on the precision of both the stem profile and basic wood density models; according to the results obtained in the present study, in both cases it is advantageous to incorporate tree state variables, i.e. by developing individual tree models. This is reflected in the best estimate of stem profile and basic wood density, and solves the problems of over- and underestimation observed in other methods (details at Barrio et al. 2007).

Diameter at breast height (DBH) and the total tree height were adequate state variables to explain residual variability induced by individual-tree effects on both stem taper and basic wood density. These pairs of easy-to-measure tree variables are the same used by traditional indirect methods for estimating stem biomass (see e.g. Brown et al. 1989, Myers 1990, Husch 2001, Diéguez et al. 2003, Specht and West 2003, Pérez and Kanninen 2002, Fonseca et al. 2009) and both are captured by customary forest inventory; thus, no additional effort is required to practical use of the flexible biomass equation presented in this paper.

\section{CONCLUSIONS}

Most accurate stem diameter and basic wood density estimates are obtained from individual tree models. Thus, the most accurate estimates of biomass, based on combinations of stem profile and basic wood density models, are obtained combining individual tree models. The flexible equation of stem biomass obtained for the Populus $x$ canadensis, I-488 variety not only estimates stem biomass with high precision, but also enables the estimation of the biomass between any two points of the stem, which represents a great advantage compared with traditional biomass models which only estimate the total biomass of the stem or up to a specific top merchantable diameter. In addition, this equation, together with the stem profile model, constitutes a simple system of equations that allow complementary mass-volume quantification of the stem. Thus, depending on the final use of timber and on the dimensions of the tree, a fraction of the stem can be quantified in units of volume and the remaining fraction in weight units.

\section{REFERENCES}

Akaike H. 1974. A new look at the statistical model identification. IEEE Transactions on Automatic Control 19: 716-723. Barrio M, H Sixto, I Cañellas, F González. 2007. Sistema de cu- bicación con clasificación de productos para plantaciones de Populus x euramericana (Dode) Guinier cv. 'I-214' en la meseta norte y centro de España. Investigación Agraria: Sistemas y Recursos Forestales 16(1): 65-75.

Beaudoin M, RE Hernandez, A Koubaa, J Poliquin. 1992. Interclonal, intraclonal and within-tree variation in wood density of poplar hybrid clones. Wood and Fiber Science 24(2): 147-153.

Bhat K, KV Bhat, T Dhamodaran. 1990. Wood density and fiber length of Eucalyptus grandis grown in Kerala, India. Wood and Fiber Science 22: 54-61.

Brown S, A Gillespie, A Lugo. 1989. Biomass estimation methods for tropical forests with applications to forest inventory data. Forest Science 35(4): 881-902.

Bruce D, R Curtis, C Vancoevering. 1968. Development of a system of taper and volume tables for red alder. Forest Science 14: 339-350.

Bruce D. 1975. Evaluating accuracy of tree measurements made with optical instruments. Forest Science 21: 421-426.

Clark N. 2001. Longitudinal density variation in irrigated hardwoods. Appita Journal 54 (1): 49-53.

Díaz G, S Monteoliva, J Álvarez, E Fernández, 2010. Populus deltoides 'Australiano 129/60': variación axial de la densidad y desarrollo de un modelo predictivo de la densidad del árbol completo. Bosque 31(1): 65-72.

Diéguez U, M Barrio, F Castedo, AD Ruiz, MF Alvarez, JG Alvarez y A Rojo. 2003. Dendrometría. Madrid, España. Ediciones Mundi-Prensa. 327p.

Downes GM, IL Hudson, CA Raymond, AJ Dean, AJ Michell, LR Schimleck, R Evans, A Muneri. 1997. Sampling Eucalyptus for wood and fibre properties. Melbourne, Australia. CSIRO Publishing. $132 \mathrm{p}$.

Earikäinen K. 2001. Stem volume models with random coefficients for Pinus kesiya in Tanzania, Zambia, and Zimbabwe. Canadian Journal of Forest Research 31: 879-888.

Fang SZ, WZ Yang. 2003. Interclonal and within-tree variation in wood properties of poplar clones. Journal of Forestry Research 14 (4): 263-268.

Fonseca WG, F Alice, JM Rey. 2009. Modelos para estimar la biomasa de especies nativas en plantaciones y bosques secundarios en la zona Caribe de Costa Rica. Bosque 30(1): 36-47.

Gaillard de Benítez C, M Pece, M Juárez de Galídez, A Maldonado, VH Acosta. 2000. Biomasa aérea de quebracho blanco (Aspidosperma quebracho-blanco) en dos localidades del Parque Chaqueño seco. Quebracho 9:115-127.

Gutiérrez A, MV Baonza. 2001. Propiedades físicas de la madera de diferentes clones de chopo. In I Simposio del Chopo, Zamora, España. p. 461-468.

Harris J, DJ Cown. 1991. Basic wood properties. In Kininmonth JA, LJ Whitehouse eds. Properties and uses of new zealand radiata pine. Rotorua, New Zealand. Forest Research Institute. 238 p.

Husch B. 2001. Estimación del contenido de carbono de los bosques. In Simposio internacional Medición y monitoreo de la captura de carbono en ecosistemas forestales. Valdivia, Chile.

Igartúa DV, SM Rivera, MG Monterubbianesi, SE Monteoliva, S Farina, SL Carranza, MS Villegas. 2002. Calidad del leño en Eucalyptus globulus ssp. globulus: II. Variaciones en la densidad básica y la longitud de fibras en Lobería, provincia de Buenos Aires, Argentina. Revista de la Facultad de 
Agronomía de La Plata 105(1): 29-39

Igartúa D, S Monteoliva. 2010. Densidad básica, longitud de fibras y crecimiento en dos procedencias de Eucalyptus globulus en Argentina. Bosque 31(2): 150-156.

Kohyama T, M Hotta. 1990. Significance of allometry in tropical saplings. Functional Ecology 4: 515-521.

Monteoliva S, C Núñez, D Igartúa. 2002. Densidad básica, longitud de fibras y composición química de una plantación de Eucalyptus globulus de la Provincia de Buenos Aires, Argentina. In II Congreso Iberoamericano de Investigación en Celulosa y Papel (CIADICYP). Sao Pablo, Brasil. 8 p.

Moya R, A Berrocal, JR Serrano, M Tomazello. 2009. Variación radial de la anatomía, densidad y durabilidad de la Madera de teca (Tectona grandis) procedente de dos calidades de sitio y dos regiones climáticas de Costa Rica. Investigación Agraria: Sistemas y Recursos Forestales 18(2): 119-131.

Muñoz C, J Cancino, M Espinosa. 2005. Análisis de biomasa del vuelo de un rodal adulto de Pinus radiata. Bosque 26(3): 33-44.

McKinley RB, CJ Shelbourne, CB Low, B Penellum, MO Kimberley. 2002. Wood properties of young Eucalyptus nitens, E. globulus and E. maidenii in Northland, New Zealand. New Zealand Journal of Forestry Science 32(3): 334-356.

Myers RH. 1990. Classical and modern regression with applications. USA. PWS-Kent Publishing Company. 488 p.

Navar J, N González, J Graciano. 2001. Ecuaciones para estimar componentes de biomasa en plantaciones forestales de Durango, México. In Simposio Internacional de Medición y Monitoreo de la Captura de Carbono en Ecosistemas Forestales. Octubre de 2011. Valdivia, Chile.

Parresol BR, CE Thomas. 1989. A density integral approach to estimating stem biomass. Forest Ecology and Management 26: 285-297.

Peredo M, C Mora, M Ramírez. 2007. Efecto del espaciamiento en la densidad básica y aptitud pulpable de la madera de Eucalyptus nitens. Concepción, Chile. Bioforest S.A. 8 p.
Pérez D, M Kanninen. 2002. Wood specific gravity and aboveground biomass of Bombacopsis quinata plantations in Costa Rica. Forest Ecology and Management 165: 1-3.

Prado A, S Barros. 1989. Eucalyptus. Principios de silvicultura y manejo. Santiago de Chile. Instituto Forestal, CORFO. $199 \mathrm{p}$.

Raymond L, Czaplewski RL, AS Brown, DG Guenther. 1989. Estimating merchantable tree volume in Oregon and Washington using stem profile models. Fort Collins, Colo., USA. Dept. of Agriculture, Forest Service, Rocky Mountain Forest and Range Experiment Station. 15 p.

Raymond CA, A Muneri. 2001. Nondestructive sampling of Eucalyptus globulus and E. nitens for wood properties. I. Basic density. Wood Science and Technology 35: 27-39.

SAS Institute inc. 2009. SAS/STAT ® 9.2 user’s guide, second edition. Cary, NC: SAS Institute Inc.

Segura M, M Kanninen. 2005. Allometric models for tree volume and total aboveground biomass in a tropical humid forest in Costa Rica. Biotropica 37(1): 2-8.

Specht A, PW West. 2003. Estimation of biomass and sequestered carbon on farm forest plantations in northern New South Wales, Australia. Biomass Bioenergy. 25: 363-379.

Schlegel B. 2001. Estimación de la biomasa y carbono en bosque de tipo forestal siempre verde. In Simposio Internacional de Medición y Monitoreo de la Captura de Carbono en Ecosistemas Forestales. Octubre de 2011. Valdivia Chile. 13 p.

Welles JM, S Cohen. 1996. Canopy structure measurement by gap fraction analysis using commercial instrumentation. Journal of Experimental Botany 47: 1335-1342.

Wagenmakers E, S Farrell. 2004. AIC model selection using Akaike weights. Psychonomic Bulletin y Review 11(1): 192-196.

Zobel BJ, JR Sprague. 1998. Juvenile wood in forest trees. Berlin, Germany. Springer-Verlag. 299 p.

Zobel BJ, J Talbert. 1988. Técnicas de mejoramiento genético de árboles forestales. Buenos Aires, Argentina. Limusa. 545 p. 